\title{
HRM-Performance Perspectives: An Overview of Theoretical Challenges and Prospects
}

\author{
Ahmed Ullah Shah ${ }^{1}$, Muhammad Ishfaq Khan ${ }^{2}$ \\ ${ }^{1}$ Iqra National University, Peshawar \\ Phase II, Hayatabad, Peshawar, Pakistan \\ E-mail.Shah2138@gmail.com \\ ${ }^{2}$ Muhammad Ali Jinnah University, Islamabad \\ Islamabad Expressway, Kahuta Road, Zone-V, Islamabad \\ E-mail.ishfaq@jinnah.edu.pk \\ cross $^{\text {ref }}$ http://dx.doi.org/10.5755/j01.ee.30.3.9550
}

\begin{abstract}
The research on human resource management (HRM) and performance claims a significant positive relationship. However, some researchers doubt this relationship. The purpose of this paper is to review existing available literature regarding the nature of HRM, nature of performance, and how these two are linked? This paper evaluates the literature on HRMPerformance relationship and concludes that there are significant theoretical challenges. The review of available literature pertaining to HRM practices reflects that there is a long list of HRM practices but researchers have no consensus on common practices. The review of high performance work system (HPWS) helps us to conclude that in spite of substantial research work on bundling of HPWS, consensus could not be arrived at some common structure. Similarly, the paper provides an overview of existing theoretical perspectives and concludes that some perspective provides good theoretical and practical base for the HRM-Performance linkages. However, there is deficiency in literature concerning the alternative perspective. This paper also reviews Organizational Justice $(O J)$ as an alternative option and concludes that OJ has great scope and it could be one of the most realistic perspective in the future HRM-Performance relationship. Likewise, the review of the black box helps us to conclude that there are theoretical gaps and misconceptions in HRM-Performance relationship. The paper also provides an insight of performance and concludes that majority of researchers have focused on shareholders approach, while the stakeholders approach is largely disregarded.
\end{abstract}

Keywords: HRM Practices; HPWS; Performance; Black Box; Organizational Justice.

\section{Introduction}

Human resource management (HRM) and organizational performance (OP) have been the most common areas of research interest to the HRM Scholars, since 1994 (Jiang et al., 2012; Paauwe, 2009). In spite of the fact that HRM Scholars have succeeded in developing significant amount of literature and information in this field, they are still concerned regarding HRM-performance relationship (Wall \& Wood, 2005). Many research scholars are of the view that HRM practices have significant and positive impact on performance (Boselie et al., 2005; Paauwae \& Richardson, 1997; MacDuffie, 1995; Pundziene et al., 2007; Buoziute-Rafanaviciene et al., 2009). However, some researchers doubt this relationship (Wright \& Gardner, 2003; Wall \& Wood, 2005).

Thanks to continuous commitment of researchers, they have contributed their efforts to clear HRM-performance relationship. However, despite of the large amount of literature and knowledge, researchers still require theory of HRM, theory of performance and theory about how they are linked (Paauwe et al., 2013; Paauwae, 2009; Savaneviciene \& Stankeviciute, 2010). Guest (1997) was among the pioneers who raised three basic questions: what is HRM, what is performance, and how these two are linked? Likewise, there are theoretical and methodological problems (Paauwe \& Boselie, 2005). Similarly, (Wright \& Gardner, 2003) mentioned that HRM practices are at least weakly related to organizational performance but significant methodological and theoretical challenges exist.

This paper focuses only on theoretical errors and more specifically concentrates on the above mentioned three questions, which provide the base for this study. Moreover, it reviews and analyzes the theoretical issues in the HRMperformance relationship, which may be used to build agenda for future research. The purpose of this paper is to provide insights of the existing theoretical perspectives and to suggest a more suitable and realistic perspective for this relationship. Despite the fact that there are many theoretical perspectives, some of which did provide strong base for HRMPerformance relationship, there is still need of yet another perspective to fill the gap in existing research. Research method for this paper is to analyze and combine existing available scientific literature on HRM-performance relationship. The remaining paper is divided into three parts. The first part is devoted to HRM, high performance work system (HPWS), theoretical perspectives and organizational justice, second part focuses on the concept of performance, while, the final part covers the concept of black box.

\section{What is HRM?}

Some researchers defined HRM as an organizational "orientation" towards managing people (Panayotopoulou et al., 2003); while, other researchers made an evaluation of the 
effectiveness of HRM practices (Wright et al., 2001; Huselid et al., 1997).

The process of HRM developed over time. It expanded and extended in the form of HRM practices. The present count of such HRM practices has crossed a dozen in number in most of the cases. Jiang et al., (2012) list consists of 14 HRM practices. Similarly, (Pfeffer, 1994) has earlier provided a list of $16 \mathrm{HRM}$ practices and later on reduced it to thirteen HRM practices (Pfeffer et al., 1995). While, (Boselie et al., 2005), after reviewing a number of sources, have presented his own list of twenty-six HRM practices. However, (Patterson et al., 2010) list consist of only 10 HRM practices.

The sources of literature on HRM practices reviewed in above mentioned papers reflect a total number of twenty-six
HRM practices, with fewer HRM practices are common than the differences (table 1). Boselie et al., (2005) reviewed 104 journals' articles, published between 1994 and 2003, and found that the top four HRM practices were training and development, contingent pay and reward schemes, performance management (including appraisal), and careful recruitment and selection. However, the commonalities among the aforementioned list of HRM practices include: recruitment and selection, compensation and rewards, training and development, performance management, sharing information, and employee involvement. The sources of literature reflect much development of HRM and its broader coverage, which has broadened the mental horizon of people concerned with management of human resources.

Table 1

Comparison between HRM Practices

\begin{tabular}{|c|c|c|c|}
\hline $\begin{array}{l}\text { Pfeffer (1994) \& Patterson et } \\
\text { al., (2010) Commonalities }\end{array}$ & $\begin{array}{l}\text { Pfeffer (1994) \& Patterson et } \\
\text { al., (2010) Differences }\end{array}$ & $\begin{array}{l}\text { Pfeffer (1994) \& Boselie et al., } \\
(2005) \text { Commonalities }\end{array}$ & $\begin{array}{c}\text { Pfeffer (1994) \& Boselie et al., (2005) } \\
\text { Differences }\end{array}$ \\
\hline $\begin{array}{l}\text { (i) Staffing } \\
\text { (ii) Training \& development } \\
\text { (iii) Compensation and rewards } \\
\text { (iv) Performance management } \\
\text { (v) Communication } \\
\text { (vi) Employee involvement } \\
\text { (vii) Single status } \\
\text { (viii) Job security }\end{array}$ & $\begin{array}{l}\text { (i) Work design } \\
\text { (ii) Family friendly } \\
\text { (iii) Bundles } \\
\text { (iv) Employment security } \\
\text { (v) Wage compression across } \\
\text { levels } \\
\text { (vi) Promotion from within } \\
\text { (vii) Teams \& job redesign } \\
\text { (viii) Cross training and cross } \\
\text { utilization, } \\
\text { (ix) Long term perspective } \\
\text { (x) Overarching vision }\end{array}$ & $\begin{array}{l}\text { (i) Employment security } \\
\text { (ii) Recruitment \& selection } \\
\text { (iii) 'Good' wages } \\
\text { (iv) Training \& development } \\
\text { (v) Sharing information } \\
\text { (vi) Symbolic egalitarianism } \\
\text { (vii) Team working \& } \\
\text { collaboration } \\
\text { (viii) Performance management } \\
\text { (ix) Contingent pay \& rewards } \\
\text { (x) Internal promotion } \\
\text { (xi) Employee ownership } \\
\text { (xii) Participation and } \\
\text { empowerment }\end{array}$ & $\begin{array}{l}\text { (i) Wage compression across levels } \\
\text { (ii) Cross training and cross utilization } \\
\text { (iii) Long term perspective } \\
\text { (iv) Overarching vision/rationale } \\
\text { (v) Job design } \\
\text { (vi) Social responsibility practices } \\
\text { (vii) Formal procedures } \\
\text { (viii) HR planning } \\
\text { (ix) Attitude survey } \\
\text { (x) Diversity \& equal opportunities } \\
\text { (xi) Job analysis } \\
\text { (xii) Socialization \& social activities } \\
\text { (xiii) Family-friendly policies \& work life } \\
\text { balance (WLB) } \\
\text { (xiv) Employee exit management } \\
\text { (xv) Professionalization \& effectiveness of } \\
\text { the HR function/department }\end{array}$ \\
\hline $\begin{array}{l}\text { Pfeffer (1994) \& Jiang et al., } \\
\text { (2012) Commonalities }\end{array}$ & $\begin{array}{l}\text { Pfeffer (1994) \& Jiang et al., } \\
\text { (2012) Differences }\end{array}$ & $\begin{array}{c}\text { Patterson et al., (2010) \& } \\
\text { Boselie et al., (2005) } \\
\text { Commonalities }\end{array}$ & $\begin{array}{l}\text { Patterson et al., (2010) \& Boselie et al., } \\
\text { (2005) Differences }\end{array}$ \\
\hline $\begin{array}{l}\text { (i) Recruitment \& selection } \\
\text { (ii) Information sharing } \\
\text { (iii) Training \& development } \\
\text { (iv) Performance appraisal } \\
\text { (v) Compensation } \\
\text { (vi) Incentives } \\
\text { (vii) Promotion \& career } \\
\text { development } \\
\text { (viii) Job security } \\
\text { (ix) Work teams } \\
\text { (x) Employee involvement }\end{array}$ & $\begin{array}{l}\text { (i) Overarching vision } \\
\text { (ii) Job design, } \\
\text { (iii) Formal grievance \& } \\
\text { complaints } \\
\text { (iv) Symbolic egalitarianism, } \\
\text { (v) Wage compression across } \\
\text { levels } \\
\text { (vi) Employee ownership } \\
\text { (vii) job redesign } \\
\text { (viii) Cross training and cross } \\
\text { utilization, } \\
\text { (ix) Long term perspective and }\end{array}$ & $\begin{array}{l}\text { (i) Recruitment \& selection } \\
\text { (ii) Training\& development } \\
\text { (iii) Performance management } \\
\text { (iv) Compensation \& reward } \\
\text { (v) Job design } \\
\text { (vi) Communication } \\
\text { (vii) Employee involvement } \\
\text { (viii) Single status } \\
\text { (ix) Family friendly }\end{array}$ & $\begin{array}{l}\text { (i) Bundles } \\
\text { (ii) Team working \& collaboration } \\
\text { (iii) Internal promotion opportunities } \\
\text { (iv) Autonomy \& decentralization } \\
\text { (v) Diversity and Equal opportunities } \\
\text { (vi) Employment security } \\
\text { (vii) Formal procedures } \\
\text { (viii) HR planning } \\
\text { (ix) Attitude survey } \\
\text { (x) Diversity } \\
\text { (xi) Job analysis } \\
\text { (xii) Socialization \& social activities } \\
\text { (xiii) Employee exit management } \\
\text { (xiv) Professionalization \& effectiveness of } \\
\text { the HR function/department } \\
\text { (xv) Social responsibility practices }\end{array}$ \\
\hline $\begin{array}{l}\text { Patterson et al., (2010) \& Jiang } \\
\text { et al., (2012) Commonalities }\end{array}$ & $\begin{array}{c}\text { Patterson et al., (2010) \& } \\
\text { Jiang et al., (2012) } \\
\text { Differences } \\
\end{array}$ & $\begin{array}{c}\text { Boselie et al., (2005) \& Jiang et } \\
\text { al., (2012) } \\
\text { Commonalities }\end{array}$ & $\begin{array}{c}\text { Boselie et al., } \\
\text { Differences }\end{array}$ \\
\hline $\begin{array}{l}\text { (i) Work design } \\
\text { (ii) Recruitment \& selection } \\
\text { (iii) Compensation } \\
\text { (iv) Training \& development } \\
\text { (v) Sharing information } \\
\text { (vi) Participation \& involvement } \\
\text { (vii) Performance management }\end{array}$ & $\begin{array}{l}\text { (i) Family friendly } \\
\text { (ii) Single status } \\
\text { (iii) Bundles } \\
\text { (iv) Promotion } \\
\text { (v) Job security } \\
\text { (vi) Work teams } \\
\text { (vii) Formal grievances and } \\
\text { complaints }\end{array}$ & $\begin{array}{l}\text { (i) Recruitment \& selection } \\
\text { (ii) Training and development } \\
\text { (iii) Performance appraisal } \\
\text { (iv) Compensation } \\
\text { (v) Incentives } \\
\text { (vi) Benefits } \\
\text { (vii) Promotion \& career } \\
\text { development } \\
\text { (viii) Job design } \\
\text { (ix) Job security } \\
\text { (x) Employee involvement } \\
\text { (xi) Formal grievance } \\
\text { (xii) Information sharing } \\
\text { (xiii) Work teams }\end{array}$ & $\begin{array}{l}\text { (i) Autonomy \& decentralization } \\
\text { (ii) HR planning } \\
\text { (iii) Financial participation } \\
\text { (iv) Symbolic egalitarianism } \\
\text { (v) Attitude survey } \\
\text { (vi) Social responsibility practices } \\
\text { (vii) Indirect participation } \\
\text { (viii) Job analysis } \\
\text { (ix) Professionalization \& effectiveness of } \\
\text { the HR function/department } \\
\text { (x) Diversity \& equal opportunities } \\
\text { (xi) Socialization \& social activities } \\
\text { (xii) Family-friendly policies \& work life } \\
\text { balance (WLB) } \\
\text { (xiii) Employee exit management }\end{array}$ \\
\hline
\end{tabular}




\section{High Performance Work System (HPWS)}

Sufficient literature is available wherein experts have tried to arrive at selecting a few relatively most important and relevant HRM practices, through categorizing and building the 'bundles' of those practices and conceiving 'HPWS'. This section is dedicated to review the literature regarding such efforts. Ichniovski et al., (1993) were amongst the earlier researchers who found that 'bundles' of HRM practices have greater effect on performance than individual practices (Ichniovski et al., 1993; Huselid, 1995). Such "bundles" of HRM practices have been referred to as high involvement, high commitment, and HPWS. However, the above concepts refer to same philosophy, but are used interchangeably (Drummond \& Stone, 2007; Bae et al., 2011; Connolly \& McGing, 2007; Chow, 2005; Evans \& Davis, 2005).

Datta et al., (2005) define HPWS practices as a "bundle" of HRM practices which have been developed for enhancing the skills, commitment, and productivity of the employee to enable employee with sustainable competitive advantage for their organization. Subramony (2006) defines that the term includes activities to develop skillful and motivated force by using sound HR practices, namely, selection of employees, rewarding of performance, training/development, and involvement of employees. However, after critically reviewing 104 journals' research articles published between 1994 and 2003, (Boselie et al., 2005) have found 58 research articles wherein an organization's HRM could be defined as discrete and multiple practices which have no explicit or discernible linkage between them. Moreover, 46 research articles wherein a more strategically minded system approach was used which viewed HRM as a bundle of integrated and coherent mutually reinforcing practices.

Some researchers are of the view that performance of the HPWS is situational, and such a system can better work in the manufacturing sector compared to the services. Macduffie (1995) used data for the year 1989-90 relating to 62 assembly plants of automobiles. He investigated two hypotheses: (i) the HR practices which are innovative affect performance as inter-related HR bundle/system; and (ii) such bundles contribute to productivity and quality when used as integrated with manufacturing policies of a flexible production system. Similarly, (Appelbaum et al., 2000), on the basis of their visits of 44 plants and surveys of more than 4,000 employees, wrote the book which explains why HPWS pay off in manufacturing case. They conclude that organizations are very successful when supervisors share knowledge with their workers, delegate powers to them, and when subordinates assume responsibility and discretion. They mentioned that workers of self-directed teams coordinated too quickly in the work process. People working in apparel had higher hourly earnings while people working in steel had both higher hourly earnings and higher job satisfaction.

Lepak \& Snell (2002) have explained that the uniqueness of human capital differentiates on the basis of four modes of employment which includes knowledgebased and job-based employment, contract work, and partnership. They further add that each of these four modes of employment associates with specific type of HR configuration referred to as commitment-based, productivity-based, compliance-based, and collaborative respectively. Likewise, (Raziq, 2011) compared manufacturing with service-based SMEs and found significant differences in the adoption of the kinds of HPWS. He indicates that service-based SMEs adopt formal HPWS, relative to manufacturing SMEs. Appelbaum et al., (2011) stated that work practices provide benefits to different types of stakeholders such as customers, shareholders, employees and employers However, such practices could not be executed in a "cookbook" manner rather they should be customized to specific work settings and industries. This suggests that sustaining competitive advantage would require introduction of new technologies, integrated approach to capital investment, and execution of HPWS tailored to the specific industry and technology.

\section{Existing Theoretical Perspectives (Existing Theories)}

Looking in to the question 'Are HRM practices really associated with performance?', Carroll et al., (2007) have referred four perspectives, which includes: universalistic perspective, contingency perspective, configurational perspective, and resource-based view. Some other authors have also discussed three more perspectives, namely: ability, motivation and opportunity (AMO) theory, fully integrated model and social exchange theory (Boselie et al., 2005; Katou, 2012).

1. According to Carroll et al., (2007), the universalistic perspective suggests that 'there is a list of HRM practices that could be implemented in any organization/situation and would have an impact on organizational performance'. However, according to Carroll et al., (2007), 'to date there is no agreement in existing literature regarding a common list of HRM practices that constitutes best practices'. Moreover, there is limited empirical support for this perspective (Venkatraman, 1989; Michie \& Sheehan, 2005; Carroll et al., 2007).

2. The contingency model is the opposite of universal model. In the contingency model which there is no specific set of HRM practices, rather HRM practices changes according to organization policies. HRM practices will only be effective if they are consistent with organizational strategies and other contextual factors such as firm size, industry, or operational policies. According to this perspective, there are three types of "fit" with respect to an organization's HRM practices and relevant context. The first fit is horizontal fit that requires the consistency among various HR practices within a firm. The second fit is vertical fit that refers to the degree to which these practices are consistent with the organizational culture, firm's strategy, and other internal factors. The third fit is external fit that refers to the degree to which HRM practices align with specific aspects of the external environment. However, (Wright \& Snell, 1998) do not agree with these three fits. They describe "fit" as a temporary approach. They further argue that organizations need to adopt dynamic approaches regarding HRM. And as environment changes, the organizations should be able to adjust itself pertaining to 
HRM practices. So in this regard there is a fit-flexibility paradox (Carroll et al., 2007).

3. The configurational perspective is a more holistic approach that concerns as to how the cluster of various factors relates with an outcome, rather than how individual factor relate to their outcomes. This approach thus implies that bundles of HRM practices have significant impact on performance, rather than individual HRM practice. Hence, adoption and implementation of relevant bundles of HRM practices have the ability to boost organizational performance. However, the irrelevant bundle of HRM practices can also affect performance in negative direction. In addition, as reviewed earlier and as (Guest et al., 2004) mentioned, there is little consensus on which practices should be combined to constitute effective bundles.

4. The fourth perspective, Resource-Based View (RBV), suggests that organizations gain competitive advantage when they have unique resources. Such resources are rare, valuable, and difficult for competitors to imitate, and then utilize those resources in such a way as to optimize the overall organization profit. Lado \& Wilson (1994) argue that the HRM practices system can lead to competitive advantage by building competencies such as knowledge, skills and abilities (KSAs) which are specific to organization, its history, culture, and produce implicit organizational knowledge. Moreover, sustaining competitive advantage through people would require a careful consideration to HRM (Kazlauskaite \& Buciuniene, 2008). However, there are many implications of this perspective. First, firms should concentrate on their workforce, including employee KSAs that is expected, in turn, to contribute positively to firm performance at the aggregate level. Second, organizations need to develop such systems which have ability to use the full potential of their workforce. Finally, this perspective suggests that an organizational HRM practices would be a feasible of the organization's culture, which refers to accepted norms, beliefs and values, functions both as an antecedent to the HRM system and as a mediator to firm performance (Bowen \& Ostroff, 2004). However, there are some very strong arguments against the stated RBV perspectives. It is said that, in situation when both the demand and supply of labour are homogenous, there is no variance in individual contribution to the firm. In this situation, it is not possible to create value through investment in human assets. It is further argued that human resources are commodity and not rare. The organizational culture, norms and team production are imitable - can be replicated in a vast number of cases. Wright et al., (1994) mentioned that, since human resources are highly mobile, a competing firm does not have to imitate the human resources of the focal firm, it can simply hire them away. Recently, Priem and Butler (2001) mentioned that there is no clear understanding of the "black box" involved in using rare, valuable, inimitable, and nonsubstitutable resources to achieve and sustain a competitive advantage. To solve this issue, Sirmon, Hitt, \& Ireland (2007) have tried to "look inside that black box" and clarify as to how valuable resources could be better managed to gain superior quality for customers which in turn helps the organization to achieve a competitive advantage.

5. Katou \& Budhwar (2008) and (Katou, 2009) have talked about the fully integrated perspective of HRM - employees' performance linkages, and argued that business strategy is not formulated in isolation; rather HRM strategy and business strategy are developed 'simultaneously', and not separately. Fully integrated model thus suggests 'simultaneity', which means that business and HRM strategies should be formulated as a whole, in determining business performance.

6. According to $A M O$ theory, three components (employees' ability, motivation and opportunity to participate) lead organization towards improved organizational performance $(\mathrm{P})$ in manufacturing industries (Appelbaum et al., 2000).

\section{$\mathrm{P}=\mathrm{f}(\mathrm{A}, \mathrm{M}, \mathrm{O})$}

In simple words, organizational performance will be enhanced when HR practices lead to ability, motivation, and provide an opportunity to employees to contribute to the effectiveness.

7. The Social Exchange Theory (SET), originally introduced in the 1960s, primarily focuses on the behavior of individuals when they interact with one another. In a recent review of the theory, (Cropanzano \& Mitchell, 2005) observe that SET is one the most important theory in organizational behavior, in spite of some of its unresolved theoretical ambiguities. Referring to the social exchange relationships, the authors add that certain workplace antecedents lead to interpersonal connections, which are evolved when employers "take care of employees", suggesting that the social exchange relationship acts as a mediator, which produce effective work behavior and positive employee attitudes. The authors add that workers form distinguishable social exchange relationships, with their immediate supervisor, coworkers, employing organizations, customers, and suppliers. These distinct relationships have implications on behavior, specifically such individuals return the benefits they receive. In this regard, the authors have quoted examples from previous researches carried out, under five different models of relational constructs, these are:

Model 1: Perceived Organizational Support (POS) and Leader-Member Exchange (LME).

Model 2: Support to commitment.

Model 3: Adding team support to organizational support.

Model 4: Adding supervisory support.

Model 5: Trust.

Like other perspectives, social exchange theory also has certain limitations. For example, (Zafirovski, 2005) have criticized this theory at two levels. The first level belongs to the treatment of human behavior, while the second belongs to the reduction of social interaction or 'exchange' to economic transaction or a psychological process. The theory has been widely adopted in organizational research to explain employment relationships in the workplace (Shapiro \& Shore, 2007; Shapiro \& Conway, 2004). Few researchers contend that the organization cannot be a party in employee and employer relationship, but the party is the agent himself who represent the organization (Shapiro \& Shore, 2007).

8. Some researchers suggest that a mixture of two or more than two perspectives be used to complete HRMperformance linkages. Boselie et al., (2005) found that researchers are largely combining two to three perspectives to take insights from them, such popular theories are, AMO 
theory, resource based view, and contingency theory to make overall theory of HRM. These theories seem to provide complementary frameworks: AMO's attention to employee's ability, motivations and opportunities to participate acts as a theory for HRM; RBV provides a starting point, a belief in the value of employees' input into performance, while contingency theory provides a lens on the possible link between these two theories. However, as (Boselie et al., 2005) have opined, "researchers generally have not reached to an agreement regarding the operationalizations of these theories, so these theories remain only a starting point".

9. Paauwe \& Boselie (2005) work entitles 'HRM and Performance: What's Next?', which they have built on the basis of earlier contributions of several researchers (Boxall, 2003; Deephouse, 1999; Baron \& Kreps, 1999; Dyer \& Shafer, 1999). Their model advocates for achievement of critical HRM goals, and critical non HRM goals. According to their model, there is the need of a balance between costeffectiveness HR goals, the organizational flexibility urgency, and the social legitimacy dimensions, that is, $a$ balanced HR perspective (Deephouse, 1999).

Paauwe \& Boselie (2005) mentioned that, the critical HRM goals can only be achieved, when employees are fairly treated. They further suggest that, HRM system should consist of both economic (cost effectiveness and flexibility) and relational rationality (social legitimacy and fairness towards individuals) (Deephouse, 1999). Fairness and legitimacy refers to building good relationship with all stakeholders (Paauwe, 2004). Organizations who fail to achieve the objective of fairness and legitimacy will lead their people to perceive injustice by those involved (inside and outside stakeholders) and affect both employee behavior and social relations within an organization. Moreover, achieving the criteria of fairness and legitimacy in true spirit means that HR managers need to treat their people with dignity and respect. This also means that the message communicated to people through HR practices by HR managers needs to be clear, consistent, and uniformly applied.

Despite the prevalence of large number of different perspectives, there is no agreement amongst researchers on common perspective. However, the similarities amongst these perspectives are; all have foundation in HRM practices and its possible outcomes. Moreover, all perspectives are based on a linear causal process (Savaneviciene \& Stankeviciute, 2010). Some perspectives did provide good theoretical foundations to take insight from, for developing a practical base for HRM-Performance linkage. However, there is still deficiency in literature pertaining to alternate perspective (Boselie et al., 2005; Savaneviciene \& Stankeviciute, 2010). There is a great need to consider which of the stated perspectives would need to be combined and how, so that the need of alternate theory be covered. Moreover, some researchers proposed 'organizational justice' as one of the alternative perspective (Paauwae, 2009; Paauwae \& Boselie, 2005; Boselie et al., 2013), which needs a separate detailed discussion in the following sub-section.

\section{Organizational Justice (OJ): Alternate Perspective (Proposed Theory)}

The literature presented on the eight HRMperformance perspectives would not fulfill the objective of this paper unless it does not include a discussion on $O J$ and its prospects as an alternative option to be used in place of HRM practices in the HRM-performance relationship. Recently, researchers like (Paauwae, 2009; Paauwae \& Boselie, 2005; Boselie et al., 2013) argue that, due to different contexts and organizational settings we need additional theory for HRM. They have also suggested $O J$ for HRM-performance research, which according to them need further exploration. This sub-section therefore first introduces the concept of OJ and then critically reviews its prospects whether or not it would provide a better alternative, if used at place of HRM practices/HPWS.

The concept of OJ refers to employee perceptions regarding how employees are treated and the outcomes they receive are reasonable, impartial, and in compliance with ethical and moral standards (Cropanzano et al., 2007; Greenberg, 1990). The theory of justice has been developed from one to two, two to three and then to four dimensions (Colquitt, 2001; Colquitt \& Shaw, 2005; Colquitt et al., 2001). Distributive justices (DJ) refer to the employee's perceptions regarding the distribution of resources, which includes benefits, rewards, recognition, pay, and promotions etc. People compare their inputs and outputs to that of other employees. Employee's assessment that inducements are unfair and unjust leads them to perceive treatment as unfair (Adam, 1965; Leventhal, 1976; Colquitt, 2012; Fischer, 2012). Procedural justice (PJ) is the employee's perceptions concerning the fairness of the decision-making processes. Employee's assessment that managers and corporation adopt unfair practices and procedures to reach the decisions leads them to perceive treatment as unfair (Leventhal, 1980; Thibaut \& Walker, 1975; Greenberg \& Folger, 1983). Interpersonal justice (INPJ) is the level to which employees within organization are treated with politeness, respect and dignity by supervisors (Bies \& Moag, 1986; Colquitt, 2001). The assessment that they are not treated with dignity and respect will lead to perceptions of unfair treatment (Bies \& Moag, 1986; Colquitt, 2001; Greenberg, 1993). Finally, the Informational justice (INFJ) refers to information convey to people are adequate, true and on time. Employees assessment that information is untrue or not on the time and do not provide sufficient explanations leads to perceptions of unfair treatment (Bies \& Moag, 1986; Colquitt, 2001; Greenberg, 1993; Colquitt \& Zipay, 2015).

The review of OJ and its dimensions sets a stage to assess whether or not it could replace the existing HRM practices/HPWS and eight perspectives discussed in detail in the immediate preceding section. Literature provides adequate support for OJ and its four major dimensions (Paauwae, 2004; Paauwae \& Boselie, 2005; Paauwae \& Boselie, 2007; Purcell \& Kinnie, 2007; Paauwae, 2009; Boselie et al., 2013). Paauwae \& Boselie (2005) mentioned that to date, little attention has been paid to OJ/legitimacy and flexibility, and these two might turn out to be a more realistic perspective in future HR research. While, in their other work (Paauwae \& Boselie, 2007), they have explicitly mentioned "new institutionalism", the concept of 
“organizational justice", and "organizational legitimacy” as suitable options to understand the shaping of HRM practices. In this connection, (Boselie et al., 2005) have also proposed legitimacy and ethicality in the cases pertaining to HRM. Likewise, (Purcell \& Kinnie, 2007) mentioned that the feedback of employees pertaining to HRM practices and their perceptions of them, not only in terms of policies and practices, but in terms of fairness and justice would take us back to what HRM really is. Moreover, (Boselie et al., 2013) have also suggested organizational justice for HRMPerformance relationship. In his earlier study, (Paauwae, 2009) mentioned that organizational Justice needs further exploration, which can forward the field of HRM in general and HRM-Performance relationship in particular. The sources of literature reviewed in this section reflect that OJ has a great scope and vast space. It can be a more practical perspective in future HRM-Performance relationship.

\section{What is Performance?}

Guest (1997) proposed that it is more logical to use the word outcomes than performance. This was also earlier proposed by (Dyer \& Reeves, 1995). They suggested multidimensional concept of performance such as HRM outcomes, organizational outcomes, and financial outcomes. The HR related outcomes include attitudes and behavior, organizational outcomes include productivity, quality, efficiencies, and financial outcomes include profit and sales. Wright \& Gardner (2003) have mentioned the relevance of multidimensional concept in two broad aspects; (1) HRM outcomes are closer to HRM practices than other outcomes. (2) HRM practices effect distal outcomes (financial outcomes) through HRM outcomes. These arguments also support our theoretical model provided in figure 1. That is, HRM practices affect distal outcomes (financial outcomes) through HRM outcomes (employees attitude and behavior), as they are more proximal to HRM practices.

However, Paauwae (2009) on the basis of (Boselie et al., 2005) overview concluded that, researchers have largely used financial measures to study HRM performance link. He endorsed (Guest, 1997) argument that, this is quite problematic, as the distance between HRM practices and financial performance is too large and might be due to other business activities (e.g. research and development). Purcell \& Kinnie, (2007) also identified two fundamental problems in financial measures. First, it is far away from HRM practices. Second, financial measure takes for granted that organization seek to develop their HRM systems to optimize financial performance, mostly in the short run seen in shareholder value.

Savaneviciene \& Stankeviciute (2010) reviewed multiple models and proposed four types of performance outcomes. These outcome are HRM related outcomes, organizational outcomes, financial outcomes, and market based outcomes. HRM practices directly affect HRM related outcomes (attitude and behavior), which effect organizational outcomes (quality and efficiency), which in turn lead to financial outcomes (profit and sales), which finally lead to market based outcome. Paauwae \& Boselie (2005) after analyzing many papers suggested stakeholder approach for HRM performance relationship. They further mentioned that stakeholder approach is a more holistic and balanced approach. This approach will be a unique composition for each organization, which is difficult to imitate by competitors. Hence it lead to sustainable competitive advantage. Boselie et al., (2005), after reviewing 104 papers mentioned that majority of researchers have used shareholders approach. While employees' attitudes and behavior have been rarely used and they further suggest stakeholders approach for performance.

\section{How HRM is linked with Performance (Black Box)?}

The discussion-whether various HRM practices contribute (what, how and why), which HRM practices contribute and which ones not, and which HRM practices contribute better than others. It started getting attention of the researchers during the mid-1990s. Becker \& Gerhart (1996) were amongst the earlier researchers who pinpointed some of the 'black boxes' in the HRM practices-performance linkage. According to Boselie et al., (2005), in between HRM practices (input) and performance (output) - are possibly moderated by intervening variables - lies what HRM does to improve performance, how, and why'; this mediating mechanism is usually known a black box", as little is known, what happens in this mediating mechanism, and the contents of key variables some-what unclear'.

One of the main problems of HRM-Performance debate is the concept of black box, and what researchers have speculated about the elements or contents of the black box (Wright \& Gardner, 2003). Many researchers found significant positive relationship between HRM and performance. However, two perspectives prevail in the literature (Chand \& Katou, 2007). The first perspective demonstrates that there is a direct relationship between HRM and performance (Katou \& Budhwar, 2007), ignoring the mediating variables all together; while, the second perspective presents that HRM effect performance through some mediating variable/s (Messersmith et al., 2011; Guest et al., 2000), having little or no consensus on mediating variables.

Boselie et al., (2005) analysis of the 104 articles confirms that the mediating mechanisms between input (HRM practices) and output (performance), as well as the contents of key variables are largely disregarded in research. This exploratory analysis further proposed that HRM practices effects organizational performance through mediating mechanisms of employee attitudes and behavior. According to Savaneviciene \& Stankeviciute (2010), a good number of researchers have found the existence of black boxes. They referred to the situations as black boxes where the mechanisms between HRM and performance linkages remain unclear. They also concluded that researchers need to properly place the mediating variables in order to solve the critical problem of black box.

Collins \& Clark (2006) have look into the "black box" and found that HRM practices are significantly related to performance through the mediating mechanism of top management team networks. Moreover, Becker \& Huselid (2006) agreed that the "black box" between HRM and performance is the most significant theoretical and methodological issue in the HRM-Performance literature. However, they have suggested a focus on fully integrated 
strategy implementation as the key mediating variable in the HRM-Performance relationship.

Guest (1997) also mentioned that there is a considerable amount of literature supporting HRM-performance relationship, but in most cases it is less clear how and why this relationship exists. His model proposes that HRM practices affect employee's motivation (attitude) which influences behavior outcomes (effort, organizational citizenship) which in turn leads to performance outcomes. Similarly, in his later work, (Guest et al., 2000) proposed that employees attitude and behavior need to be included as mediating variables. Boselie et al., (2005) and Paauwae \& Boselie (2005) further reinforces the above-mentioned problems and reported that there exists a gap in literature regarding alternative theories on the concept of HRM, the concept of performance and how they are linked. They mentioned that although strategic contingency theory, resource based view and AMO are prominent perspectives used in (104) papers, but in majority cases the relationship is not clear. Paauwae \& Boselie (2005), after analyzing different models suggested that, it is appropriate to use attitudinal and behavioral outcomes between HRM \& performance, which are closer to HRM practices. Patterson et al., (2010) concluded that there is little evidence that how and in what situations HRM practices lead to performance. This review also supports that intervening or mediating variables need to be included in order to have a better understanding of the HRM-Performance relationship. Similarly, (Messersmith et al., 2011) in their study "unlocking the black box" have also mentioned that researchers agreed that HPWS works, but are not clear how this link is completed. They suggested that employee attitudinal variables such as job satisfaction, organizational commitment, and employee empowerment are important elements of the black box linking HPWS to performance. Likewise, Wright \& Nishii (2006) have also explained the mediating mechanism between HRM practices and organizational performance. They reported employee's reactions are the significant elements of the black box. It is important to mention that employee's reactions include both employee's attitudes (affective \& cognitive) and behavior. In this context, Becker et al., (1997) models proposed that HRM system is influenced by business strategies. HRM practices have direct impact on employee's motivation (attitude) which in turn leads to employee's creativity, productivity, and discretionary behavior (behavior), which consequently result in operational performance.

It has been confirmed, by many sources of literature, that there exist both direct and indirect link between HRM and performance. However, researchers by and large suggest that HRM-performance relationship should be measured through the mediating mechanism of employees' attitude \& behavior (see Figure 1). This was also mentioned earlier by (Wright \& Gardner, 2000) that there is consensus regarding one issue, that any theoretical or empirical research should at least specify some mediating variables. Moreover, it is also evident that employee attitudes and behavior are the core elements of black box, as suggested by researchers (Patterson et al., 2010; Nishii et al., 2008; Baron \& Kenny, 1986; Dellery \& Doty, 1996; Paauwae, 2004; Lepak et al., 2006; Katou, 2008; Savaneviciene \& Stankeviciute, 2010; Boselie et al., 2005; Paauwae \& Boselie, 2005; Guest, 1997; Wright \& Nishii, 2006; Guest et al., 2000; Messersmith et al., 2011; Katou, 2011; Becker et al., 1997; Katou, 2012).

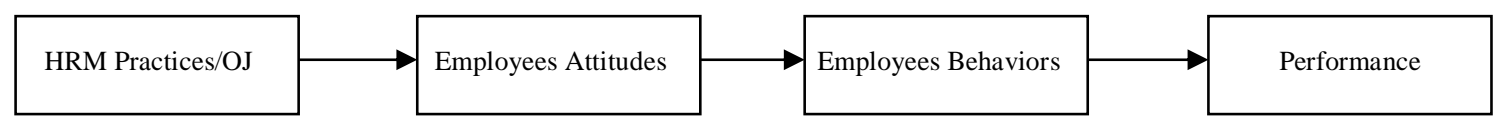

Figure 1. The Mediating Mechanism of HRM-Performance Relationship

Source: Developed by the Authors

Review of literature presented in this section indicates that considerable number of researchers have recognized the problem of black box. Moreover, many researchers share similar concepts of the black box (table 2). The statements given in table 2 demonstrate that the underlying mechanism between HRM and performance is not yet clear. Hence, there is a need of underlying theory. Researchers specifically suggest incorporating relevant mediators to fill the gaps and black boxes in the stated relationship. Whereas researchers have recognized the problem of black box, they have also proposed its key elements, that is, employee's attitudes and their behavior (see Figure 1). The literature helps to identify employees' attitudes and their behavior as the important elements of black box. Therefore, the problem could be solved with the inclusions of stated two outcomes. However, one could argue that there exist multiple employees' attitudes, which one could take priority. One way to solve this issue is through indexation; by including all relevant attitudes and behavior in the econometric model and computing their index for subsequent measurement.

Table 2

\section{Propositions of the "Black Box"}

\begin{tabular}{|l|l|}
\hline \multicolumn{1}{|c|}{ Author } & \multicolumn{1}{c|}{ Concept of black box } \\
\hline Savaneviciene \& Stankeviciute (2010) & $\begin{array}{l}\text { Although many conceptual models have tried to clear the processes, the underlying mechanism is still not } \\
\text { clear. }\end{array}$ \\
\hline Boselie et al., (2009) & $\begin{array}{l}\text { This study concluded that almost 30 years have passed; there still exist dualities, paradoxes, and ambiguities } \\
\text { in HRM performance relationship. }\end{array}$ \\
\hline Patterson et al., (2010) & $\begin{array}{l}\text { This systematic review concluded that there is little evidence how, and in what situations, HRM practices } \\
\text { lead to organizational performance. }\end{array}$ \\
\hline Boselie et al., (2005) & $\begin{array}{l}\text { In between HRM practices (input) and organizational performance (output) - are possibly moderated by } \\
\text { intervening variables - lies what HRM does to improve performance, how, and why'; this mediating } \\
\text { mechanism is usually known as "black box", as little is known, what happens in this mediating mechanism. }\end{array}$ \\
\hline
\end{tabular}




\section{Conclusions}

1. There is a long list of HRM practices, and there has been little agreement amongst experts on common HRM practices. The experts and practitioners are concerned as to which of the HRM practices are relatively more important, which warrant priority in implementation relative to the other practices. However, the common six HRM practices include: recruitment and selection, compensation and rewards, training and development, performance management, sharing information, and employee involvement.

2. In spite of heavy research work carried out on informal categorizing of HRM practices, bundling, and development of HPWS, consensus could not be arrived at some common structure of HPWS. It may be said that HPWS vary in impact from situation to situation, industry to industry and organization to organization. As a result one cannot generalize HPWS for all situations and organizations. There is strong theoretical support for developing HPWS, and there is a great need to do so, even if it can be possible on situational basis, for situation-tosituation and industry-to-industry.

3. Of the eight existing perspectives, some perspectives provide good theoretical foundations to take insights from, for building a strong and practical base for the HRMperformance linkages. Such promising perspectives especially include: RBV, AMO theory, Fully-integrated model, SET, and Balanced HR perspective. There seems a need to deeply consider which of the aspects of some of the stated practically-more-important perspectives would need to be combined, and how, so that the academically researched and identified gaps be taken care off.

4. The similarities amongst the existence perspectives are: all have foundation in HRM practices and its possible outcomes; and all perspectives are based on a linear causal process. Despite the prevalence of large number of different perspectives, there is no consensus amongst the scholars on common perspective/theory. Hence, there is still a need of alternate theory of HRM.

5. While, in literature the most suitable option for alternate perspective/theory is OJ and its major dimensions. OJ has great scope and it could be one of the most realistic perspectives in future HRM-Performance relationship. OJ has a vast space and it could replace the existing HRM practices/HPWS and perspectives. Moreover, it is a better option which has been developed over time in both theory and practice, to the extent that it provides a relatively better and greater sense of 'fairness' and 'justice' to the employees of any organization.

6. There also exist theoretical gaps, and misconceptions in the existing research. Furthermore, there is strong need of framing research basing it on relevant theories. Whereas, researchers have recognized the problem of black box, they have also proposed employees attitude and behavior as the key elements of black box. Therefore, there is a need to incorporate relevant mediators, such as, employee's attitude and behavior to fill the gaps and black boxes.

7. Majority of researchers have focused on shareholders approach, while stake holders approach is largely disregarded. Wherever, researchers criticized shareholders approach, they have also proposed stakeholders approach for HRM-performance relationship. Stake holders approach encompasses all stakeholders with their particular interest within organization. Researchers need to adopt stakeholders' approach in order to cover the complex and multi-dimensional concept of performance.

8. This study contributes to the literature by providing insights of almost all existing perspectives and identifies "organizational justice" as a more realistic perspective. Further, employee's attitudes and behavior could be used to overcome the problem of the black box. Moreover, it proposes that multiple stake holders should be used to understand the multi-dimensional concept of performance.

\section{References}

Adams, J. S. (1965). Inequity in social exchange. Advances in experimental social psychology, 2, $267-299$. https://doi.org/10.1016/S0065-2601(08)60108-2

Appelbaum, E., Gittell, J. H., \& Leana, C. (2011). High-Performance Work Practices and Sustainable Economic Growth. Downloaded from:http://www.employment policy.org/sites/www.employmentpolicy.org/files/field-content file/pdf/Mike Lillich/High Performance Work Practices 3-20-11_0.pdf

Appelbaum, E., Bailey, T., Berg, P., \& Kalleberg, A. (2000). Manufacturing Advantage: Why High- Performance Work Systems Pay Off, Ithaca, NY: Cornell University Press.

Bae, K.S., Chuma, H., Kato, T., Kim, D. B., \& Ohashi, I. (2011). High Performance Work Practices and Employee Voice: A Comparison of Japanese and Korean Workers. Industrial Relations: A Journal of Economy and Society, 50(1), 129. https://doi.org/10.1111/j.1468-232X.2010.00623.x

Baron, J. N., \& Kreps, D. (1999). Consistent human resource practices. In California Management Review, 41(13), $29-31$. https://doi.org/10.2307/41165996

Baron, R. M., \& Kenny, D. A. (1986). The moderator-mediator variable distinction in social psychological research: conceptual, strategic, and statistical considerations. Journal of Personality and Social Psychology, 51, 1173-1182. https://doi.org/10.1037/0022-3514.51.6.1173

Becker, B. E., \& Huselid, M. A. (2006). Strategic human resources management: where do we go from here? Journal of management, 32(6), 898-925. https://doi.org/10.1177/0149206306293668 
Becker, B. E., \& Gerhart, B. (1996). The impact of human resource management on organizational performance: Progress and prospects. Academy of Management Journal, 39, 779-801. https://doi.org/10.2307/256712

Becker, B. E., Huselid, M. A., Pickus, P. S., \& Spratt, M. F. (1997). HR as a source of shareholder value: research and recommendations. Human Resource Management, 36(1), 39-47. https://doi.org/10.1002/(SICI)1099050X(199721)36: 1<39::AID-HRM8>3.0.CO;2-X

Bies, R. J., \& Moag, J. F. (1986). Interactional justice: Communication criteria of fairness. In R. J. Lewicki, B. H. Sheppard, \& M. H. Bazerman (Eds.). Research on negotiations in organizations, 1, 43-55.

Boselie, J. P. P. E. F., Paauwe, J., \& Farndale, E. (2013). The contribution of HRM to fairness, social legitimacy and public value: human resource governance and risk management in seven leading multinationals companies. In P. Leisink, P. Boselie, M. van Bottenburg, \& D. M. Hosking (eds.), managing social issues: A public values perspective (pp. 238257). Cheltenham: Edward Elgar. https://doi.org/10.4337/9781781006962.00023

Boselie, P., Brewester, C., \& Paauwe, J. (2009). In search of balance- managing the dualities of HRM: an overview of the issues. Personnel review, 38 (5), 461-471. https://doi.org/10.1108/00483480910977992

Boselie, P., Dietz, G., \& Boon, C. (2005). Commonalities and contradictions in HRM and performance research. Human Resource Management Journal, 15 (3), 67-94. https://doi.org/10.1111/j.1748-8583.2005.tb00154.x

Bowen, D. E., \& Ostroff, C. (2004). Understanding HRM-firm performance linkages: The role of the 'strength' of the HRM system. In: Academy of Management Review, 29, 203-221. https://doi.org/10.5465/amr.2004.12736076

Boxall, P. (2003). HR strategy and competitive advantage in the service sector. Human Resource Management Journal, 13(3), 5-20. https://doi.org/10.1111/j.1748-8583.2003.tb00095.x

Buoziute-Rafanaviciene, S., Pundziene, A., \& Turauskas, L. (2009). Relation between the attributes of executive successor and organizational performance. Inzinerine Ekonomika-Engineering Economics(2), 65-74.

Carroll, W. R., Wagar, T. H., Rondeau, K. V., \& Gilson, C. H. J. (2007). Looking inside the black box: Are human resource practices really associated with employer performance? ASAC Ottawa, Ontario.

Chand, M., \& Katou A. A. (2007). The impact of human resource management on organisational performance in the Indian hotel industry. Employee Relations, 29(6), 576-594. https://doi.org/10.1108/01425450710826096

Chow, I. H. S. (2005). High-performance work systems in Asian companies. Thunderbird International Business Review, 47(5), 575-599. https://doi.org/10.1002/tie.20068

Collins, C. J., \& Clark, K. D. (2003). Strategic human resource practices, top management team social networks, and firm performance: The role of human resource practices in creating organizational competitive advantage. Academy of management Journal, 46(6), 740-751. https://doi.org/10.2307/30040665

Colquitt, J. A. (2001). On the dimensionality of organizational justice: A construct validation of a measure. Journal of Applied Psychology, 86, 386-400. https://doi.org/10.1037/0021-9010.86.3.386

Colquitt, J. A. (2012). Organizational justice. Oxford Handbook of Organizational Psychology, 1, 526-547. https://doi.org/10.1093/oxfordhb/9780199928309.013.0016

Colquitt, J. A., \& Shaw, J. C. (2005). How should organizational justice be measured? In J. Greenberg \& J. A. Colquitt (Eds.), the handbook of organizational justice (pp. 113-152). Mahwah, NJ: Erlbaum.

Colquitt, J. A., \& Zipay, K. P. (2015). Justice, fairness, and employee reactions. Annual Review of Organizational Psych \& Organizational Behavior, 2, 1-25. https://doi.org/10.1146/annurev-orgpsych-032414-111457

Colquitt, J. A., Conlon, D. E., Wesson, M. J., Porter, O. L. H. C., \& Ng, K. Y. (2001). Justice at the Millennium: A metaAnalytic review of 25 years of organizational justice research. Journal of applied psychology, 86(3), 425-445. https://doi.org/10.1037/0021-9010.86.3.425

Connolly, P., \& McGing, G. (2007). High performance work practices and competitive advantage in the Irish hospitality sector. International Journal of Contemporary Hospitality Management, 19(3), 201-210. https://doi.org/10.1108 /09596110710739903

Coyle-Shapiro, J. A. M., \& Conway, N. (2004). The employment relationship through the lens of social exchange. In J. Coyle-Shapiro, L. Shore, S. Taylor, \& L. Tetrick (Eds). The employment relationship: Examining psychological and contextual perspectives. Oxford: Oxford University press.

Cropanzano, R., \& Mitchell, M. S. (2005). Social exchange theory: An interdisciplinary review. Journal of management, 31, 874-900. https://doi.org/10.1177/0149206305279602

Cropanzano, R., Bowen, D. E., \& Gilliland, S., W. (2007). The management of organizational justice, Academy of Management Perspectives, 34-48. https://doi.org/10.5465/amp.2007.27895338 
Ahmed Ullah Shah, Dr. Muhammad Ishfaq Khan. HRM-Performance Perspectives: An overview of Theoretical Challenges...

Datta, D. K., Guthrie, J. P., \& Wright, P. M. (2005). Human resource management and labor productivity: does industry matter? Academy of Management Journal, 48(1), 135-145. https://doi.org/10.5465/amj.2005.15993158

Deephouse, D. L. (1999). To be different, or be the same? It's a question (and theory) of strategic balance. Strategic Management Journal, 20, 147-66. https://doi.org/10.1002/(SICI)1097-0266(199902)20:2<147::AID-SMJ11> 3.0.CO;2-Q

Delery, J., \& Doty, D. H. (1996). Modes of theorizing in strategic human resource management: test of universalistic, contingency and configurational performance predictions. Academy of Management Journal, 39, 802-835. https://doi.org/10.5465/256713

Drummond, I., \& Stone, I. (2007). Exploring the potential of high performance work systems in SMEs. Employee Relations, 29(2), 192-207. https://doi.org/10.1108/01425450710720011

Dyer, L., \& Shafer, R. A. (1999). From human resource strategy to organizational effectiveness: lessons from research on organizational agility. Research in Personnel and Human Resource Management, 4, 145-174.

Dyer, L., \& Reeves, T. (1995). HR strategies and firm performance: what do we know and where do we need to go. International Journal of Human Resource Management, 6(3), 656-670. https://doi.org/10.1080/09585199 500000041

Evans, W. R., \& Davis, W. D. (2005). High-performance work systems and organizational performance: The mediating role of internal social structure. Journal of Management. 31(5), 758-775. https://doi.org/10.1177/014920 6305279370

Ferris, G. R., Arthur, M. M., Berkson, H. M., Kaplan, D. M., Harrell-Cook, G., \& Frink, D. D. (1998). Toward a social context theory of the human resource managementorganization effectiveness relationship. Human Resource Management Review, 8, 235-264. https://doi.org/10.1016/S1053-4822(98)90004-3

Fischer, R. (2012). Organizational justice research: present perspectives and challenges. Revista Psicologia: Organizacoes e Trabalho, 12(1), 97-112

Greenberg, J. (1990). Organizational Justice: Yesterday, today and tomorrow. Journal of Management, 16, 399-432. https://doi.org/10.1177/014920639001600208

Greenberg, J. (1993). The social side of fairness: Interpersonal and informational classes of organizational justice. In R. Cropanzano (Ed.), Justice in the workplace: Approaching fairness in human resource management (pp.79-103). Hillsdale, NJ: Erlbaum.

Greenberg, J., \& Folger, R. (1983). Procedural justice, participation, and the fair process effect in groups and organizations. In P. B. Paulus (Ed.), Basic Group Processes: 235-256. New York: Springer-Verlag. https://doi.org/10.1007/978-14612-5578-9_10

Guest, D. (1997). Human resource management and performance: A review and research agenda. International Journal of Human Resource Management, 8 (3), 263-267.https://doi.org/10.1080/095851997341630

Guest, D., Michie, J., Sheehan, M., \& Conway, N. (2000). Getting Inside the HRM - Performance Relationship. ESRC Future of Work Programme Working Paper No. 8.

Guest, D. E., Conway, N., \& Dewe, P. (2004). Using sequential tree analysis to search for bundles of HR practices". Human Resource Management Journal, 14 (1), 79-96. https://doi.org/10.1111/j.1748-8583.2004.tb00113.x

Huselid, M. A. (1995). The impact of human resource management practices on turnover, productivity, and corporate financial performance. Academy of Management Journal, 38, 635-72. https://doi.org/10.2307/256741

Huselid, M. A., Jackson, S. E., \& Schuler, R. S. (1997). Technical and strategic human resource management effectiveness as determinants of firm performance. Academy of Management Journal, 40 (1), 171-188. https://doi.org/10. $2307 / 257025$

Ichniowski, C., Shaw, K., \& Prennusli, G. (1993). The effects of human resource management practices on productivity. : Working paper, Columbia University.

Jiang, K., Lepak, D., P. Jiahu, \& Baer, J., C. (2012). How does human resource management influence Organizational outcomes? A meta-analytic investigation of mediating mechanisms. Academy of Management Journal, 55(6), 1264 1294. https://doi.org/10.5465/amj.2011.0088

Katou, A. A. (2008). Measuring the impact of HRM on organizational performance. Journal of industrial engineering and management, 01(02), 119-142. https://doi.org/10.3926/jiem.2008.v1n2.p119-142

Katou, A. A. (2008). Test of a causal Human Resource Management-Performance Linkage Model: Evidence from the Greek manufacturing sector. Journal of Business Science and Applied Management, Volume 6 (1).

Katou, A. A. (2009). The impact of human resource development on organizational performance: Test of a causal model. Institute of Behavioral and Applied Management. 
Katou, A. A. (2012). 'Modelling causal relationships between employee perceptions of manager's leadership behavior, satisfaction with HR practices, and organizational performance: the case of Greece', Int. J. Modelling in Operations Management, 2 (2), 173-203. https://doi.org/10.1504/IJMOM.2012.046339

Katou, A. A., \& Budhwar, P. S. (2007). The effect of human resource management policies on organisational performance in Greek manufacturing firms. Thunderbird International Business Review, 49, 1-35. https://doi.org/10.10 02/tie. 20129

Katou, A. A., \& Budhwar, P. S. (2008). The effect of business strategies and HRM policies on organizational performance: The Greek experience. Global Business and Organizational Excellence: A Review of Research \& Best Practices, 4057. https://doi.org/10.1002/joe.20235

Kazlauskaite, R., \& Buciuniene, I. (2008). The role of human resources and their management in the establishment of sustainable competitive advantage. Inzinerine Ekonomika-Engineering Economics, (5), 78-84.

Lado, A., \& Wilson, M. (1994). Human Resource Systems and Sustained Competitive Advantage: A Competency-based Perspective. Academy of Management Review, 19, 699-727. https://doi.org/10.5465/amr.1994.9412190216

Lepak, D. P., \& Snell, S. A. (2002). Examining the human resource architecture: the relationship among human capital, employment, and human resource configurations. Journal of Management, 28(4), 517-543. https://doi.org/10.11 77/014920630202800403

Lepak, D. P., Liao, H., Chung, Y., \& Harden, E. E. (2006). A conceptual review of human resource management systems in strategic human resource management research. Research in Personnel and Human Resources Management, 25, 217-271. https://doi.org/10.1016/S0742-7301(06)25006-0

Leventhal, G. S. (1976). The distribution of rewards and resources in groups and organizations. In L. Berkowitz \& W. Walster (Eds.), Advances in experimental social psychology (Vol. 9, pp. 91-131). New York: Academic Press. https://doi.org/10.1016/S0065-2601(08)60059-3

Leventhal, G. S. (1980). What should be done with equity theory? New approaches to the study of fairness in social relationships. In K. Gergen, M. Greenberg, \& R. Willis (Eds.), Social exchange: Advances in theory and research (pp. 27-55). New York: Plenum Press. https://doi.org/10.1007/978-1-4613-3087-5_2

MacDuffie, J. P. (1995). Human resource bundles and manufacturing performance: organizational logic and flexible production systems in the world auto industry. Industrial and Labor Relations Review, 48, 197-221. https://doi.org/10.1177/001979399504800201

Messersmith, J. G., Lepak, D. P., \& Patel, P. C. (2011). Unlocking the black box: Exploring the link between high performance work system and performance. Journal of applied psychology, 96 (6), 1105-1118. https://doi.org/10.10 $37 / \mathrm{a} 0024710$

Michie, J., \& Sheehan, M. (2005). Business Strategy, Human Resources, Labour Market Flexibility and Competitive Advantage. International Journal of Human Resource Management, 16, 445-464. https://doi.org/10.1080/ 0958519042000339598

Nishii, L. H, Lepak, D. P., \& Schneider, B., (2008). Employee Attributions of the "Why" of HR Practices: Their Effects on Employee Attitudes and Behaviours, and Customer Satisfaction. Personnel Psychology, 61(3), 503-545. https://doi.org/10.1111/j.1744-6570.2008.00121.x

Paauwe, J. (2004). HRM and Performance: Achieving Long-term Viability. Oxford: Oxford University Press. https://doi.org/10.1093/acprof:oso/9780199273904.001.0001

Paauwe, J. (2009). HRM and Performance: Achievements, Methodological Issues and Prospects. Journal of Management Studies, 46 (1). https://doi.org/10.1111/j.1467-6486.2008.00809.x

Paauwe, J., \& Boselie, P. (2005). HRM and performance: what next? Human Resource Management Journal, 15, 68-83. https://doi.org/10.1111/j.1748-8583.2005.tb00296.x

Paauwe, J., \& Boselie, P. (2007). HRM and Societal Embeddedness. In P. Boxall, J. Purcell, \& P. Wright (Eds.), Oxford Handbook of Human Resource Management (pp. 166-184). New York: Oxford University Press.

Paauwe, J., \& Richardson, R. (1997). Introduction to special issue on HRM and performance. International Journal of Human Resource Management, 8, 257-262. https://doi.org/10.1080/095851997341621

Paauwe, J., Wright, P., \& Guest, D. (2013). HRM and performance: what do we know and where should we go? In J. Paauwe, D. Guest, \& P. Wright (Eds.), HRM and Performance: Achievements and Challenges (pp. 1-13). Chichester, Sussex: Wiley.

Panayoyopoulou, L., Bourantas, D. \& Papalexandris, N. (2003). Strategic human resource management and its effects on firm performance: an implementation of the competing values framework. International Journal of Human Resource Management, 14 (4), 680-699. https://doi.org/10.1080/0958519032000057781 
Ahmed Ullah Shah, Dr. Muhammad Ishfaq Khan. HRM-Performance Perspectives: An overview of Theoretical Challenges...

Patterson, M., Rick, J., Wood, S., Carroll, C., Balain, S., \& Booth, A. (2010). Systematic review of the links between human resource management practices and performance. Health Technology Assessment, 14(51). https://doi.org/10. 3310/hta14510

Pfeffer, J. (1994). Competitive Advantage through People. California Management Review, 36 (2), 9-28. https://doi.org/10. 2307/41165742

Pfeffer, J., Hatano, T., \& Santalainen, T. (1995). Producing sustainable competitive advantage through the effective management of people. Academy of management executive, 9 (1), 55. https://doi.org/10.546 5/ame.1995.9 503133495

Priem, R. L., \& Butler, J. E. (2001). Is the resource-based "view" a useful perspective for strategic management research? Academy of Management Review, 26(1), 22-40. https://doi.org/10.5465/amr.2001.4011928

Pundziene, A., Alonderiene, R., \& Buoziute, S. (2007). Managers' change communication competence links with the success of the organizational change. Inzinerine Ekonomika-Engineering Economics, (4), 61-69.

Purcell, J., \& Kinnie, N. (2007). HRM and Business Performance. In P. Boxall, J. Purcell, \& P. Wright (Eds.), Oxford Handbook of Human Resource Management (pp. 533-551). New York: Oxford University Press.

Raziq, A. (2011). High performance management practices in manufacturing and service based SMEs. A comparative study. '24th annual SEAANZ conference' held in Australia technology Park Sydney on 13th to 15th July. https://doi.org/10.1037/e605342012-026

Savaneviciene, A., \& Stankeviciute, Z. (2010). The Models Exploring the "Black Box" between HRM and Organizational Performance. Inzinerine Ekonomika- Engineering Economics, 21(4), 426-434.

Shapiro, J, A., \& Shore, L, M. (2007). The employee- organization relationship: where do we go from here? Human Resource Management Review, 17, 166-179. https://doi.org/10.1016/j.hrmr.2007.03.008

Sirmon, D. G., Hitt, M. A., \& Ireland, R. D. (2007). Managing firm resources in dynamic environments to create value: Looking inside the black box. Academy of management review, 32(1), 273-292. https://doi.org/10.54 65/amr.2007.23466005

Subramony, M. (2006). Why organizations adopt some human resource management practices and reject others: An exploration of rationales. Human Resource Management, 45(2), 195-210. https://doi.org/10.1002/hrm.20104

Thibaut, J., \& Walker, L. (1975). Procedural justice: A Psychological analysis. Hillsdale, NJ: Erlbaum.

Venkatraman, N. (1989). The Concept of Fit in Strategy Research: Toward a Verbal and Statistical correspondence. Academy of Management Review, 14, 423-444. https://doi.org/10.5465/amr.1989.4279078

Wall, T. D., \& Wood, S. J. (2005). The romance of human resource management and business performance, and the case for big science. Human Relations, 58(4), 429-462. https://doi.org/10.1177/0018726705055032

Wright, P. M., \& Nishii, L. H. (2006). Strategic HRM and organizational behaviuor: integrating multiple levels of analysis. CARHS Working Paper Series, 05. Available at: 〈http://ilr.corneli.edu/CAHRS〉.

Wright, P. M., \& Gardner, T. M. (2003). The human resource-firm performance relationship: methodological and theoretical challenges. in Holman, D., Wall, T.D., Clegg, T.D., Sparrow, P., Howard, A. (Eds), The New Workplace: A Guide to the Human Impact of Modern Working Practices, Wiley, Chichester.

Wright, P., \& Snell, S. (1998). Toward a Unifying Framework for Exploring Fit and Flexibility in Strategic Human Resource Management. Academy of Management Review, 23, 756-772. https://doi.org/10.5465/amr.1998.1255637

Wright, P. M., McMahan, G., Snell, S. A., \& Gerhart, B. (2001). Comparing line and HR executive's perceptions of HR effectiveness: services, roles and contributions. Human Resource Management, 40 (2), 111-123. https://doi.org/10.1002/hrm.1002

Wright, P. M., McMahan, G.C., \& McWilliams, A. (1994). Human resources and sustained competitive advantage: a resource-based perspective. International Journal of Human Resource Management, 5(2), 301-326. https://doi.org/10.1080/09585199400000020

Zafirovski, M. (2005). Social Exchange Theory under Scrutiny: A positive critique of its economic-behaviorist formulations. Electronic journal of sociology.

The article has been reviewed.

Received in January 2015; accepted in June 2019. 